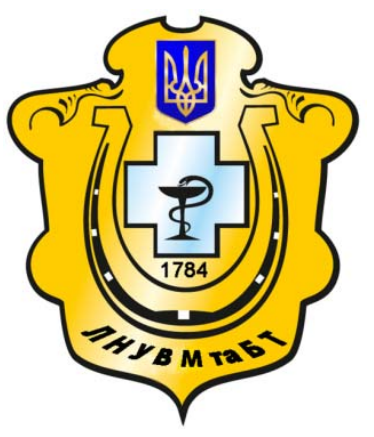

Науковий вісник Львівського національного університету ветеринарної медицини та біотехнологій імені С.3. Гжицького

Scientific Messenger of Lviv National University of Veterinary Medicine and Biotechnologies named after S.Z. Gzhytskyj

doi:10.15421/nvlvet7028

ISSN 2413-5550 print

ISSN 2518-1327 online

$\underline{\text { http://nvlvet.com.ua/ }}$

УДК 619:616.98:577.115.3

\title{
Вміст ліпідів у сироватці крові корів за спонтанного інфікування віру- сом лейкозу великої рогатої худоби
}

\author{
Л.М. Іщенко, В.Д. Іщенко, В.Г. Спиридонов \\ ischenko_lm@ukr.net \\ Національний університет біоресурсів і природокористування Украӥни, \\ вул. Героїв Оборони, 15, м. Київ, 03041, Украӥна
}

\begin{abstract}
Ліпіди відіграють важливу роль у біологічному ицклі та регуляиії експресії ретровірусів. Зокрема у процесах, пов'язаних з взаємодією із ліпідним бішаром клітини-господаря (проникнення вірусу в клітину) $і$ відбрунькування синтезованих вірусних частин. Для ветеринарної медицини дослідження впливу вірусу лейкозу на обмін ліпідів в організмі інфікованих тварин $є$ актуальним питанням. Це обумовлено тим, щя зміни внутрішнього середовища організму під впливом вірусу лейкозу відображаються, в периу чергу, на системі крові. Водночас зміни у системі крові лактуючих корів значною мірою впливають на кількісні біохімічні показники складу молока, що впливає на його якість, поживність і безпеку для споживачів

Досліджено ліпідний склад сироватки крові корів спонтанно інфікованих вірусом лейкозу великої рогатої худоби. Для дослідження було сформовано дві групи корів чорно-рябої породи 3-річного віку на 3 - 4 місяиі лактації, масою тіла 400450 кг, по 6 голів у кожній. У першій (контрольній) групі були клінічно здорові тварини, вільні від вірусу лейкозу ВРХ (за результатами РІД, ІФА та ПЛР досліджень), у другій (дослідній) знаходились інфіковані вірусом лейкозу ВРХ тварини. Встановлено, що у інфікованих тварин вірогідно збільшується вміст загальних фосфоліпідів на 6,0\% та загального і естерифікованого холестеролу на 4,3 i 4,2, відповідно При ивьому співвідношення загального холестеролу до загальних фосфоліпідів залишалося незмінним у тварин обох груп. Також у сироватиі крові корів дослідної групи відмічали збільшення на 83,3\% вмісту вільних жирних кислот. Отже, за спонтанного інфікування вірусом лейкозу великої рогатої худоби у тварин відбувається порушення якісного та кількісного складу ліпідів сироватки крові внаслідок порушення синтетичних прочесів у печінщі, спричинених необхідністю пластичного матеріалу для побудови ліпідного шару оболонки збудника.
\end{abstract}

Ключові слова:лейкоз ВРХ, сироватка крові, ліпіди, загальний холестерол, загальні фосфоліпіди, вільні жирні кислоти.

\section{Содержание липидов в сиворотке крови коров при спонтанном инфици- ровании вирусом лейкозакрупного рогатогоскота}

\author{
Л.М Ищенко, В.Д. Ищенко, В.Г. Спиридонов \\ ischenko_lm@ukr.net \\ Наџиональный университет биоресурсов и природопользования Украины, \\ ул. Героев Обороны, 15, г. Киев, 03041, Украина
}

\begin{abstract}
Липиды принимают значительное участие в биологическом иикле и регуляции экспрессии ретровирусов. В частности, 8 прочессах, связанных с взаимодействием с липидным бислоем клетки-хозяина (проникновение вируса в клетку) и отпочкованием вновь синтезированных вирусных частичек. Для ветеринарной медицины исследования влияния вируса лейкоза на обмен липидов в организме инфицированных животных является очень актуальным. Это обусловлено тем, что изменения внутренней среды организма под влиянием вируса лейкоза отражаются, в первую очередь, на системе крови. В то же время изменения в системе крови лактируюших коров в значительной степени влияют на количественные биохимические показатели состава молока и соответственно на его качество, питательность и безопасность для потребителей
\end{abstract}

Citation:

Ishchenko, L.M., Ishchenko, V.D., Spyrydonov, V.G. (2016). Content of lipids in the blood serum of cows atthe spontaneouslyinfection of bovine leukemiavirus. Messenger LNUVMBT named after S.Z. Gzhytskyj, 18, 3(70), 119-122. 
Исследован липидный состав сыворотки крови коров спонтанно инфицированных вирусом лейкоза крупного рогатого скота. Для исследования были отобраны две группы коров чёрно-пестрой породы 3-летного возраста на 3 - 4 месяце лактации, с массой тела 400 - 450 кг, по 6 голов в каждой. В первой (контрольной) группе были клинически здоровые животные, свободные от вируса лейкоза КРС (за результатами РИД, ИФА и ПЦР исследований), во второй (опьтной) - инфицированнье вирусом лейкозу КРС животные. Показано, что у инфицированных животных увеличивается содержание общих фосфолипидов на 6,0\% а также общего и эстерефицырованного холестерола на 4,3 i 4,2\%, соответственно. При этом соотношение общего холестерола к общим фосфолипидов оставалось неизменным у животных обеих групп. Также в сыворотке крови коров опьтной группы повышалось на 83,3\% содержание свободных жирных кислот. Исходя из результатов исследования у животных при спонтанном инфицировании вирусом лейкоза крупного рогатого скота изменяется качественней и количественный состав липидов сыворотки крови в следствии нарушения синтетических прочессов в печени, которые возможно вызванные необходимостью пластического материала для построения липидного шара оболочки возбудителя.

Ключевые слова: лейкоз КРС, сыворотка крови, липиды, общчии холестерол, общие фосфолипиды, свободные жирньле кислотьл.

\title{
Content of lipids in the blood serum of cows atthe spontaneouslyinfection of bovine leukemiavirus
}

\author{
L.M. Ishchenko, V.D. Ishchenko, V.G. Spyrydonov \\ ischenko_lm@ukr.net \\ National university of life and environmental sciences of Ukraine, \\ Heroyiv Oborony Str., 11, Kyiv, 03041, Ukraine
}

\begin{abstract}
Lipids take part in the biological cycle of retroviruses and regulation of their expression. In particular, in the processes associated with the interaction with the lipid bilayer of the host cell (virus penetration into the cell), and budding of newly synthesized viral particles. To study the effect bovine leukemia virus on lipid metabolism in the host organism is very important for veterinary medicine, because of its effect on animal blood system. At the same time, changes in the blood system of lactating cows have a significant impact on the biochemical indicators of quantitative composition of the milk and therefore its quality, nutritional value and safety for consumers. Investigated the lipid composition of blood serum of cattle spontaneous infected with the virus leukemia. For study was formed by two groups of cows black-and-white breed in 3 years of age on $3-4$ months of lactation, body weight were $400-450 \mathrm{~kg}$, 6 animals in each. In the first (control) group was clinically healthy animals, free from bovine leukemia virus (according to the RID, ELISA and PCR studies), the second (experimental) was animals which infected by virus bovine leukemia. Established that in the infected animals significantly increases the content of total phospholipid by $6.0 \%$, total and esterified cholesterol by 4.3 and $4.2 \%$, respectively. Thus, the correlation of total cholesterol to total phospholipids was unchanged in both groups of animals. Also, in the blood serum of cows research groups noted increase of free fatty acids content by $83.3 \%$. Thus, at the spontaneous infection the bovine leukemia virus in animals is a disturbance qualitative and quantitative composition of blood serum lipids owing to disturbance of synthetic processes in liver, caused by the necessity in the plastic material for build lipid layer of shell pathogen.
\end{abstract}

Key words: bovineleukemiavirus, bloodserum, lipids, total cholesterol, total phospholipids, free fatty acids.

\section{Ветуп}

За даними Міжнародного епізоотичного бюро (МЕБ) лейкоз великої рогатої худоби належить до однієї з найбільш поширених і дотепер невирішених проблем промислового скотарства багатьох країн світу. Крім того, захворювання має і загальнобіологічне значення, оскільки вірус лейкозу великої рогатої худоби є морфологічно та еволюційно спорідненим із вірусом $\mathrm{T}$ клітинного лейкозу людини (Human $\mathrm{T}$ celllymphotropicvirus) i часто використовується як модельний об'єкт для вивчення молекулярних механізмів, викликаних ретровірусами неоплазій (Gillet et al., 2007).

Життєвий цикл вірусу лейкозу ВРХ, як і усіх ретровірусів, $є$ унікальним в біологічному розумінні процесів розмноження, завдяки наявності ферменту РНК-залежноїДНК-полімерази. Після проникнення збудника у цитоплазму клітини-господаря вірусна РНК, в процесі зворотної транскрипції, переходить у форму лінійної двохланцюгової молекули ДНК. Молекули, які утворилися, проникають в ядро клітини, де певна кількість лінійних молекул перетворюється в кільцеві і інтегрують в клітинний геном. Інтегрована лінійна ДНК-копіяретровірусного генома (провірус) передається дочірнім клітинам як складова частина генетичного матеріалу материнської клітини (Gulyukin et al., 1990; Katoh et al., 1991).

Безперечно, що розвиток вірусу лейкозу змінює перебіг обмінних процесів у інфікованій клітині. Водночас, при розмноженні вірусу для побудови нових вірусних частинок потрібні різноманітні структурні компоненти, потреба в яких забезпечується за рахунок ресурсів клітини-господаря. Одними 3 таких речовин є ліпіди, які необхідні для формування вірусної оболонки за умов відбрунькування від цитоплазматичної мембрани інфікованої клітини. Поряд із цим, слід зазначити, що незважаючи на велику кількість наукових робіт, присвячених проблемі лейкозу ВРХ, досі $\epsilon$ мало відомостей щодо впливу вірусу на обмін ліпідів в організмі інфікованих тварин. Заслуговує на увагу i той факт, що і в медицині це питання також не піддавалося грунтовному дослідженню. Зустрічаються лише поодинокі відомості щодо впливу вірусу герпесу на обмін ліпідів в організмі людини, а також лабораторних тварин за умов експериментального відтворення патології. У проведених експериментах встановлено здатність вірусу герпесу викликати виражену дисліпідемію (Amvroseva et al., 1995; Ishutina, 2011). 
За останніми даними літератури ліпіди відіграють важливу роль у біологічному циклі та регуляції експресії ретровірусів. Зокрема у процесах, пов'язаних з взаємодією із ліпідним бішаром клітини-господаря (проникнення вірусу в клітину) і відбрунькування синтезованих вірусних частин ключову роль відводять «ліпідним рафтам» мембран (Ono and Freed, 2005; Lingwood and Simons, 2010; Waheed, 2010). Показано, що більшість вірусів, в тому числі і ретровіруси, для проникнення в клітину і при від брунькуванні від неї, для «обгортання» нових вірусних частинок у ліпідну оболонку використовують саме ділянки ліпідних рафтів (Hamilton et al., 2003). Встановлено роль ліпідів у регуляції експресії вірусу лейкозу, пов'язану iз простагландином E2, попередником якого $є$ арахідонова кислота (C20:4n6) (Pyeon et al., 2000).

Для ветеринарної медицини дослідження впливу вірусу лейкозу на обмін ліпідів в організмі інфікованих тварин $є$ не лише актуальним, а й важливим. Це обумовлено тим, що зміни внутрішнього середовища організму під впливом вірусу лейкозу відображаються, в першу чергу, на системі крові. Так кров дуже чутливо реагує на різноманітні впливи, яким піддається організм упродовж життя. Водночас зміни у системі крові лактуючих корів значною мірою впливають на кількісні біохімічні показники складу молока, що впливає на його якість, поживність і безпеку для споживачів.

Метою роботи було дослідити вміст ліпідів у сироватці крові корів за спонтанного інфікування вірусом лейкозу великої рогатої худоби

\section{Матеріал і методи досліджень}

Дослідження проводились у відділі хроматографічного та спектрального аналізу Української лаборатоpiї якості і безпеки продукції АПК.

Для дослідження складу ліпідів сироватки крові та молока у спонтанно інфікованих тварин було сформовано дві групи корів чорно-рябої породи 3-річного віку на 3 - 4 місяці лактації, масою тіла $400-450$ кг, по 6 голів у кожній. У першій (контрольній) групі були клінічно здорові тварини, вільні від вірусу лейкозу ВРХ (за результатами РІД, ІФА та ПЛР досліджень), у другій (дослідній) знаходились інфіковані вірусом лейкозу ВРХ тварини.Утримували тварин в однакових умовах, а годівлю здійснювали згідно раціону типового для зони Полісся України.
Кров для досліджень відбирали у пробірки з вакуумною системою з підхвостової артерії, до годівлі.

Екстракцію ліпідів сироватки крові та молока здійснювали за методом I. Folchetal. (1957 р.), з використанням системи розчинників хлороформ-метанол у співвідношенні 2:1. Розділення ліпідів на фракції проводили методом тонкошарової хроматографії (Петровський В. И. и др., 1986 р.) на стандартних платівках фірми «Sorbfil» (Чеська Республіка). Ідентифікацію індивідуальних фракцій ліпідів проводили 3 використанням маркерів фірми «Sigma» (США). Кількісне визначення ліпідів проводили методом спектрофотометрії загальний i естерифікованийхолестерол визначали за допомогою ферумутрихлорного, вміст фосфоліпідів і триацилгліцеролів - гідроксаматним методом, вміст вільних жирних кислот - за допомогою 1,5 дифенілкарбазиду (Petrovskiy et al., 1996).

Для статистичної обробки результатів досліджень користувалися програмою Microsoft Office Excel. Достовірність показників оцінювали за критерієм Стьюдента з урахуванням малого числа вибірок (Коkunin, 1975).

\section{Результати та їх обговорення}

При дослідженні вмісту ліпідів у сироватці крові корів спонтанно інфікованих вірусом лейкозу, порівняно із вільними від вірусу коровами, було встановлено вірогідне збільшення вмісту загальних фосфоліпідів на 6,0\% та загального і естерифікованогохолестеролу на 4,3 і 4,2\%, відповідно (рис. 1).

При цьому співвідношення загальних фосфоліпідів до загального холестеролу залишалося незмінним у тварин обох груп. Також у сироватці крові корів дослідної групи відмічали збільшення на 83,3\% вмісту вільних жирних кислот. Чутливо реагуючи на різноманітні фактори, впливу яких піддається організм, система крові відображає стан внутрішнього середовища. Дослідження вмісту ліпідів дає можливість оцінити стан обміну ліпідів в організмі тварин за лейкозу. Розвиток вірусу лейкозу ВРХ потребує пластичного матеріалу для побудови вірусних частинок. Для формування оболонки вірусів потрібні ліпіди. Ліпідний бішар вірусних частин утворюється із плазматичної мембрани інфікованої клітини шляхом брунькування.

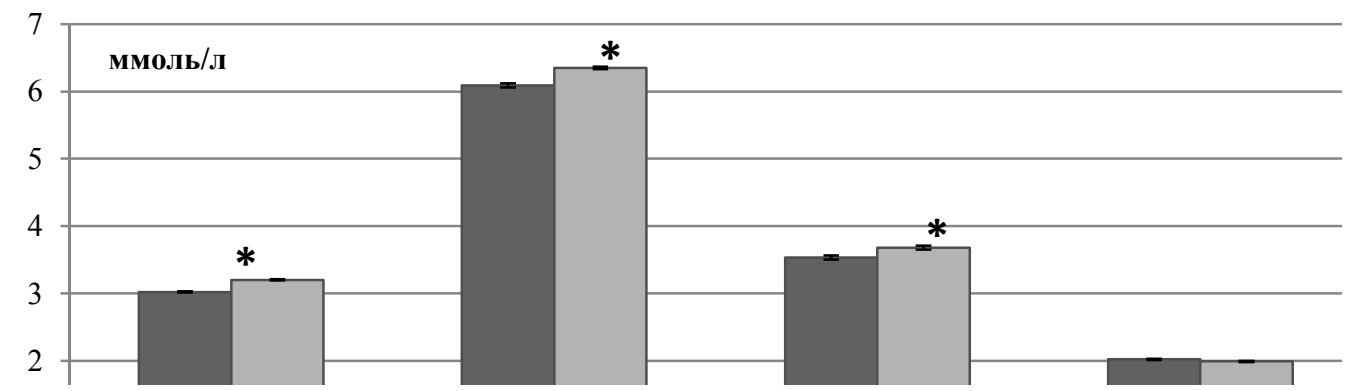

Рис. 1. Вміст ліпідів у сироватці крові корів за спонтанного інфікування вірусом лейкозу ВРХ, $\mathrm{M} \pm \mathrm{m}$, n = 6 (ФЛ - фосфоліпіди, ЗХС - холестерол загальний, ЕХС - холестеролестерифікований, ЗХС/Ф - загальний холестерол/фосфоліпіди, ТАГ - триацилгліцероли, ВЖК - вільні жирні кислоти)

Примітка. * - $\mathbf{p} \leq 0,05$ порівняно із показниками тварин контрольної групи 
Встановлено, що до складу бішару входять переважно фосфоліпіди і неестерифікований холестерол. На нашу думку вірогідне підвищення вмісту в сироватці крові тварин загального та естерифікованого холестеролу, а відповідно і вмісту неестерифікованого холестеролу підтверджують свідчить про детермінованість цих змін необхідністю синтезу бішару вірусу за розвитку лейкозної інфекції.

Вважається, що для багатьох оболонкових вірусів, репродукція яких відбувається упродовж тривалого проміжку часу, заново синтезовані молекули ліпідів інкорпоруються у віріони. Тобто, синтез ліпідів, які надалі увійдуть до складу вірусної мембрани, не припиняється і навіть активується, а при формуванні вірусних часток використовуються як ліпіди мембрани клітини-господаря, так і заново синтезовані.

Слід зазначити, що триацилгліцероли та вільні жирні кислоти забезпечують ще одну, не менш важливу, ніж структурну - енергетичну функцію. При цьому важливу роль у обміні ліпідів та їх енергетичній функції відіграють анатомо-фізіологічні особливості травного каналу жуйних тварин (Vernon, 1981). Саме у передшлунках жуйних відбувається перший етап обміну ліпідів - травний, який починається 3 перетравлення жирів корму. Окрім того, на відміну від моногастричних тварин, у жуйних суттєво відрізняється процес забезпечення енергією через особливості будови і функції їх травного каналу. У моногастричних тварин баланс енергії забезпечується переважно глюкозою (більше ніж на 90\%), у той час, як у жуйних лише на $35-45 \%$. Це обумовлює майже у 3 рази нижчі рівні глюкози у крові дорослих жуйних порівняно із моногастричними тваринами. Хоча основа енергетики тканин у жуйних мало відрізняється від моногастричних, проте у них, крім глюкози, є ще одне потужне джерело - ліпіди та жирні кислоти.

У жуйних, як і в тварин інших видів, печінка відіграє важливу роль у катаболізмі жирних кислот. Проте, згідно досліджень деяких вчених печінка у жуйних проявляє вибірковість щодо поглинання жирних кислот із крові (Ricks and Cook, 1981). При цьому відбувається переважне засвоєння пропіонату, який використовується для глікогенолізу. Порушення енергетичного обміну в організмі корів, інфікованих вірусом лейкозу $\mathrm{BPX}$, ймовірно, $є$ причиною вірогідного підвищення вмісту у сироватці крові корів вільних жирних кислот.

\section{Висновки}

Таким чином за спонтанного інфікування великої рогатої худоби вірусом лейкозу ВРХ у тварин відбувається порушення якісного та кількісного складу ліпідів сироватки крові внаслідок порушення синтетичних процесів у печінці, спричинених необхідністю пластичного матеріалу для побудови ліпідного шару оболонки вірусу лейкозу великої рогатої худоби. Це негативно впливає на стан організму інфікованих тварин, а також може призводити до зниження якості і біологічної цінності молока, отриманого від інфікованих тварин.
Перспективи подальших досліджень. Для більш глибокого вивчення стану обміну ліпідів за лейкозу ВРХ планується дослідження жирно кислотного складу ліпідів крові та молока корів, хворих на лейкоз BPX.

\section{Бібліографічні посилання}

Gillet, N., Florins, A., Boxus, M. (2007). Mechanisms of leukemogenesis induced by bovine leukemia virus: prospects for novel anti-retroviral therapies in human. Retrovirology. 18(4), 1-32.

Gulyukin, M.I. Vasin A.V., Zamaraeva, N.V. (1990). Puti peredachi virusa leykoza krupnogo rogatogo skota. Veterinariya. 1, 27-31 (in Russian).

Katoh, I., Kyushiki, H., Sakamoto, Y. (1991). Bovine leukemia virus matrix-associated protein MA (p15): further processing and formation of a specific complex with the dimer of the 5'-terminal genomic RNA fragment. J. Virol. 65, 6845-6855.

Amvroseva, T.V. Votyakov, V.I., Dyakonov, O.V. (1995). Virusyi kak faktor ateroskleroza. Meditsinskie novosti. 2, 9-20 (in Russian).

Ishutina, N.A. (2011). Linolevaya $i$ arakhidonovaya $\omega-6$ polinenasyshchennyye zhirnyye kisloty lipidov platsenty pri gerpes-virusnoy infektsii. Estestvoznaniye i gumanizm. 7(1), 33-35 (in Russian).

Lingwood, D., Simons, K. (2010). Lipid rafts as a membrane-organizing principle. Science. 327, 46-50.

Ono, A. Freed, E.O. (2005). Role of lipid rafts in virus replication. Adv. Virus Res. 64, 311-358.

Waheed, A. (2010). The Role of Lipids in Retrovirus Replication. Viruses. 2(5), 1146-1180.

Hamilton, V.T., Stone, D.M., Cantor, G.H. (2003). Translocation of the B cell receptor to lipid rafts is inhibited in B cells from BLV-infected, persistent lymphocytosis cattle. Virology. 315, 135-147.

Takahashi, T., Suzuki, T. (2011). Function of Membrane Rafts in Viral Lifecycles and Host Cellular Response. Biochem. Res. Int. Mode of access: URL: http://www.hindawi.com/journals/bri/2011/245090/

Pyeon, D.A., Diaz, F.J., Splitter, G. (2000). Prostaglandin $\mathrm{E}(2)$ increases bovine leukemia virus tax and pol mRNA levels via cyclooxygenase 2 : regulation by interleukin-2, interleukin-10, and bovine leukemia virus. Journal of Virology. 74(12), 5740-5745.

Petrovskiy, V.I., Regerand, T.I., Lysenko, E.I. (1996). Ekstraktsiya. razdeleniye i kolichestvennoye opredeleniye lipidnykh fraktsiy syvorotki krovi. Laboratornoye delo. 6, 13-16. (in Russian).

Kokunin, V.A. (1975). Statisticheskaya obrabotka dannykh pri malom chisle opytov. Ukrainskiy biokhimicheskiy zhurnal. 4(6), 776-790 (in Russian).

Vernon, R.G. (1981). Lipid metabolism in the adipose tissue of ruminant animals. Lipid of Ruminant Animals. London : Pergamon Press. 110-113.

Ricks, C.A., Cook, R.M. (1981). Regulation of volatile fatty acid uptake by mitochondrial acyl-CoA synthetasas of bovine liver. Journal of Dairy Science. 64, 2324-2335.

Стаття надійшла до редакції 27.09.2016 